\title{
Stability indicating HPLC method for the simultaneous determination of moxifloxacin and prednisolone in pharmaceutical formulations
}

\author{
Syed Naeem Razzaq ${ }^{1 *}$, Islam Ullah Khan ${ }^{1}$, Irfana Mariam² and Syed Saleem Razzaq ${ }^{3}$
}

\begin{abstract}
Background: A simple, specific, and fast stability indicating reverse phase liquid chromatographic method was established for instantaneous determination of moxifloxacin and prednisolone in bulk drugs and pharmaceutical formulations.

Results: Optimum chromatographic separations among the moxifloxacin, prednisolone and stress-induced degradation products were achieved within 10 minutes by use of BDS Hypersil C8 column ( $250 \times 4.6 \mathrm{~mm}, 5 \mu \mathrm{m}$ ) as stationary phase with mobile phase consisted of a mixture of phosphate buffer $(18 \mathrm{mM})$ containing $0.1 \%(\mathrm{v} / \mathrm{v})$ triethylamine, at pH 2.8 (adjusted with dilute phosphoric acid) and methanol (38:62 v/v) at a flow rate of $1.5 \mathrm{~mL}$ $\mathrm{min}^{-1}$. Detection was performed at $254 \mathrm{~nm}$ using diode array detector. The method was validated in accordance with $\mathrm{ICH}$ guidelines. Response was a linear function of concentrations over the range of $20-80 \mu \mathrm{g} \mathrm{mL}^{-1}$ for moxifloxacin ( $r 2 \geq 0.998$ ) and $40-160 \mu \mathrm{g} \mathrm{mL}{ }^{-1}$ for prednisolone $(r 2 \geq 0.998)$. The method was resulted in good separation of both the analytes and degradation products with acceptable tailing and resolution. The peak purity index for both the analytes after all types of stress conditions was $\geq 0.9999$ indicated a complete separation of both the analyte peaks from degradation products. The method can therefore, be regarded as stabilityindicating.
\end{abstract}

Conclusions: The developed method can be applied successfully for simultaneous determination of moxifloxacin and prednisolone in pharmaceutical formulations and their stability studies.

Keywords: Reverse phase liquid chromatography, Moxifloxacin, Prednisolone, Degradation products, ICH guidelines etc

\section{Introduction}

Moxifloxacin hydrochloride is chemically designated as 1-Cyclopropyl-6-fluoro-1,4-dihydro-8-methoxy-7-[(4aS,7aS)octahydro-6 H-pyrrolo[3,4-b]pyridin-6-yl]-4-oxo-3-quinolinecarboxylic acid hydrochloride [Figure 1]. It is a broad-spectrum antibiotic that functions by inhibiting DNA gyrase, a type II topoisomerase, and topoisomerase IV enzymes [1] necessary to separate bacterial DNA, thereby inhibiting cell replication. It is used for bacterial conjunctivitis, keratitis, pre \& post operative conditions to control the infections of the eyes. Prednisolone acetate [Figure 1] chemically designated as $11 \beta 17,21$-trihydroxypregna-1,4-diene-3,20-dione 21-acetate is a corticosteroid,

\footnotetext{
* Correspondence: naeemraindrops@yahoo.com

'Department of Chemistry, Government College University, Lahore 54000, Pakistan

Full list of author information is available at the end of the article
}

used principally for steroid-responsive inflammatory ocular conditions for which a corticosteroid is indicated and where bacterial ocular infection or a risk of infection exists [2]. Both moxifloxacin and prednisolone have been analysed by various techniques either alone or in combination with other drugs. The analytical methods existed for moxifloxacin hydrochloride included determination by spectrophotometry [3-5], and high performance liquid chromatography [6,7]. The analytical methods existed for prednisolone included determination by micellar electrokinetic chromatography [8], spectrophotometry [9], high performance liquid chromatography $[10,11]$, and thin layer chromatography densitometry [12].

The combination of moxifloxacin and prednisolone has not been adopted by any official pharmacopoeia (USP, BP or EP etc.). An extensive review of the literature did not revealed any stability indicating HPLC 

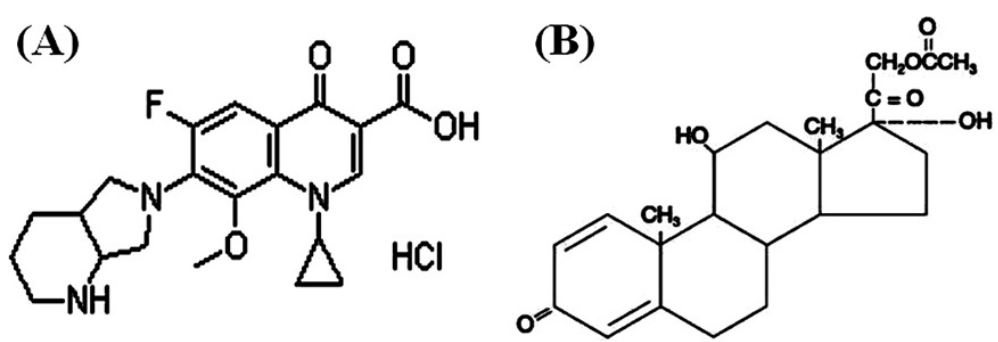

Figure 1 Chemical Structures of Moxifloxacin $\mathrm{HCl}(\mathrm{A})$ and Prednisolone Acetate (B).

method for simultaneous determination of both drugs. Therefore, attempts were made to develop and validate simple, precise, and sensitive, isocratic reverse phase stability indicating high performance liquid chromatographic method for simultaneous determination of both drugs and their degradation products in pharmaceutical formulations. We are currently engaged in binary combination analysis of different classes of drugs in pharmaceutical formulations and in human plasma [13-23].

\section{Experimental}

\section{Chemicals and reagents}

Reference standards of moxifloxacin hydrochloride and Prednisolone acetate with stated purity of 99.97 and 99.46\% respectively were obtained from Schazoo Zaka Laboratories (Lahore, Pakistan). Occumox P and Moftrex $\mathrm{P}$ eye drops (claimed to contain $5 \mathrm{mg}$ per $\mathrm{mL}$ of moxifloxacin and $10 \mathrm{mg}$ per $\mathrm{mL}$ of prednisolone) were used in this study. Occumox $\mathrm{P}$ eye drops contains $0.02 \% \mathrm{w} / \mathrm{v}$ benzalkonium chloride as preservative in sterile aqueous base and Moftrex $\mathrm{P}$ eye drops contains $0.25 \% \mathrm{w} / \mathrm{v}$ hydroxypropylmethylcellulose (HPMC) as preservative in the sterile aqueous base. Methanol (HPLC grade), potassium dihydrogen phosphate, phosphoric acid, triethylamine, sodium hydroxide, hydrochloric acid and hydrogen peroxide (analytical reagent grade) were from M.S Traders Lahore, Pakistan (Fluka origin). Double distilled water was used throughout the analysis. Mobile phase was filtered using $0.45 \mu \mathrm{m}$ nylon filters by Millipore (USA).

\section{Equipment and chromatographic conditions}

The HPLC system consisted of Shimadzu LC-20A system (Kyoto, Japan) equipped with model LC-20AT pump, SPD-M20A Diode array detector (set at $254 \mathrm{~nm}$ ), and DGU-20A5 online degasser, and a Rheodyne injection valve with a $20 \mu \mathrm{L}$ loop. Peak areas were integrated using a Shimadzu LC solution (version 1.227) software program. The experimental conditions were optimized on a BDS Hypersil C8 column ( 250 X $4.6 \mathrm{~mm}, 5 \mu \mathrm{m})$ at room temperature. Mobile phase consisted of methanol and $18 \mathrm{mM}$ phosphate buffer $(\mathrm{pH} 2.8)$ in the ratio of (62:38 v/v, respectively). The phosphate buffer was prepared by taking $2.448 \mathrm{~g}$ of potassium dihydrogen phosphate in $1000 \mathrm{~mL}$ of water. Triethylamine $(1 \mathrm{~mL})$ was added to it and $\mathrm{pH}$ was then adjusted to 2.8 using phosphoric acid. Flow rate of the mobile phase was $1.5 \mathrm{~mL} \mathrm{~min}^{-1}$ and all chromatographic experiments were performed at room temperature $\left(25^{\circ} \mathrm{C} \pm 2^{\circ} \mathrm{C}\right)$.

\section{Preparation of standard stock solution}

Stock solution was prepared to reduce the number of repetitive operations involved and hence, the chances of human or experimental error. Moreover direct weighing of moxifloxacin $\left(50 \mu \mathrm{g} \mathrm{mL} \mathrm{mL}^{-1}\right)$ and prednisolone $\left(100 \mu \mathrm{g} \mathrm{mL}^{-1}\right)$ to prepare the working standard solution cannot be performed with sufficient accuracy. Standard stock solution of moxifloxacin $\left(1250 \mu \mathrm{g} \mathrm{mL}^{-1}\right)$ and prednisolone $\left(2500 \mu \mathrm{g} \mathrm{mL}^{-1}\right)$ was prepared by accurately weighing $31.25 \mathrm{mg}$ moxifloxacin and $62.5 \mathrm{mg}$ prednisolone dissolved in 5-7 mL methanol in $25 \mathrm{~mL}$ volumetric flask and then up to the mark with mobile phase. The stock solution was used to prepare the working standard solution of moxifloxacin and prednisolone. Stock solution of moxifloxacin and prednisolone was also used to prepare working solutions for accuracy, precision, linearity $(0.4 \mathrm{~mL}-1.6 \mathrm{~mL}$ of the stock solution diluted to $25 \mathrm{~mL}$ with mobile phase), forced degradation studies (1 mL of stock solution $+1 \mathrm{~mL}$ of acid or base solution diluted to $25 \mathrm{~mL}$ with mobile phase) and robustness etc.

\section{Preparation of standard solution}

$1 \mathrm{~mL}$ of the standard stock solution was diluted to $25 \mathrm{~mL}$ with mobile phase to prepare working standard solution having concentration equal to $50 \mu \mathrm{g} \mathrm{mL} \mathrm{m}^{-1}$ of moxifloxacin and $100 \mu \mathrm{g} \mathrm{mL} L^{-1}$ of prednisolone. The solution was filtered through $0.45 \mu \mathrm{m}$ nylon filter before analysis.

\section{Preparation of sample solution}

$1 \mathrm{~mL}$ commercial eye drops (composition $5 \mathrm{mg} \mathrm{mL}^{-1}$ moxifloxacin and $10 \mathrm{mg} \mathrm{mL}{ }^{-1}$ prednisolone) were diluted to $100 \mathrm{~mL}$ with mobile phase to obtain concentration equal to $50 \mu \mathrm{g} \mathrm{mL} \mathrm{m}^{-1}$ of moxifloxacin and $100 \mu \mathrm{g} \mathrm{mL} L^{-1}$ of prednisolone. The solution was filtered through $0.45 \mu \mathrm{m}$ nylon filter before analysis. 


\section{Linearity}

Linear calibration plots of the proposed method were obtained over concentration ranges of $20-80 \mu \mathrm{g} \mathrm{mL} \mathrm{m}^{-1}$ $\left(20,30,40,50,60,70\right.$ and $\left.80 \mu \mathrm{g} \mathrm{mL}^{-1}\right)$ for moxifloxacin and $40-160 \mu \mathrm{g} \mathrm{mL}^{-1}$ prednisolone $(40,60,80,100,120$, 140 and $160 \mu \mathrm{g} \mathrm{mL} \mathrm{mL}^{-1}$ ). Each solution was prepared in triplicate.

\section{Accuracy}

Accuracy of an analytical procedure is the closeness of agreement between accepted conventional true values (reference values) and the values found. Accuracy of the developed method was determined by two ways i) standard addition method and ii) analysis of synthetic mixtures of moxifloxacin and prednisolone eye drops. In the standard addition method known quantities (50, 100 and $150 \%$ ) of moxifloxacin and prednisolone were supplemented to the sample solution previously analysed and then experimental and true values were compared. In the synthetic mixture method known quantities (50, 100 and 150\%) of moxifloxacin and prednisolone of known purity have been spiked to the placebo components (benzalkonium chloride and sodium chloride in aqueous base). Synthetic mixture (100\% nominal analytical concentration) of moxifloxacin $\left(50 \mu \mathrm{g} \mathrm{mL}^{-1}\right)$ and prednisolone $\left(100 \mu \mathrm{g} \mathrm{mL} \mathrm{m}^{-1}\right)$ was prepared by mixing moxifloxacin (500 mg), prednisolone (1000 mg), benzalkonium chloride $(0.02 \mathrm{~g})$ as preservative and sodium chloride $(0.3 \mathrm{~g})$ in $100 \mathrm{ml}$ of purified water for $30 \mathrm{~min}$ utes using magnetic stirrer. Three levels of synthetic mixtures were prepared corresponding to 50, 100 and $150 \%$ of nominal analytical concentration $(50 \mu \mathrm{g} \mathrm{mL}$ of moxifloxacin and $100 \mu \mathrm{g} \mathrm{mL} \mathrm{m}^{-1}$ of prednisolone) and analysed by the developed method.

\section{Precision}

Repeatability was studied by determination of intra-day and inter-day precision. Intra-day precision was determined by injecting five standard solutions of three different concentrations on the same day and inter-day precision was determined by injecting the same solutions for three consecutive days. Relative standard deviation (RSD\%) of the peak area was then calculated to represent precision.

\section{Specificity (stress testing)}

Stress testing was carried out using different $\mathrm{ICH}$ prescribed stress conditions such as acidic, basic, oxidative, thermal and photolytic stresses. All stress studies were performed in $25 \mathrm{~mL}$ volumetric flask.

\section{Acid degradation studies}

Acid degradation study was performed in versatile environmental test chamber (Sanyo, Japan) at $40^{\circ} \mathrm{C} / 75 \% \mathrm{RH}$ using $5 \mathrm{M} \mathrm{HCl}$. For this purpose, $1 \mathrm{~mL}$ of the standard stock solution was taken in $25 \mathrm{~mL}$ volumetric flask. One milliliter of $5 \mathrm{M} \mathrm{HCl}$ was added in the flask and kept in versatile environmental test chamber at $40^{\circ} \mathrm{C} / 75 \% \mathrm{RH}$ for $16 \mathrm{~h}$. After completion of the stress the solution was neutralized by using $5 \mathrm{M} \mathrm{NaOH}$ and completed up to the mark with mobile phase.

\section{Base degradation studies}

Base degradation study was performed at $22^{\circ} \mathrm{C} / 58 \% \mathrm{RH}$ using $5 \mathrm{M} \mathrm{NaOH}$. For this purpose, $1 \mathrm{~mL}$ of the standard stock solution was taken in $25 \mathrm{~mL}$ volumetric flask. One milliliter of $5 \mathrm{M} \mathrm{NaOH}$ was added in the flask and kept at $22^{\circ} \mathrm{C} / 58 \% \mathrm{RH}$ for forty minutes. After completion of the stress the solution was neutralized by using $5 \mathrm{M} \mathrm{HCl}$ and completed up to the mark with mobile phase.

\section{Oxidative degradation studies}

Oxidative degradation study was performed in versatile environmental test chamber (Sanyo, Japan) at $40^{\circ} \mathrm{C} / 75 \%$ $\mathrm{RH}$ using $6 \% \mathrm{H}_{2} \mathrm{O}_{2}$. For this purpose, $1 \mathrm{~mL}$ of the standard stock solution was taken in $25 \mathrm{~mL}$ volumetric flask. One milliliter of $6 \% \mathrm{H}_{2} \mathrm{O}_{2}$ was added in the flask and kept in versatile environmental test chamber at $40^{\circ} \mathrm{C} / 75 \% \mathrm{RH}$ for $16 \mathrm{~h}$. After completion of the stress, the $25 \mathrm{~mL}$ flask was completed up to the mark with mobile phase.

\section{Thermal degradation studies}

Thermal degradation studies were performed at two different temperatures i) in versatile environmental test chamber (Sanyo, Japan) at $40^{\circ} \mathrm{C} / 75 \% \mathrm{RH}$ and ii) in oven (Gallenkamp, UK) at $105^{\circ} \mathrm{C}$ (dry heat thermolysis). For this purpose, $1 \mathrm{~mL}$ of the standard stock solution was taken in two different $25 \mathrm{~mL}$ volumetric flasks and kept in versatile environmental test chamber at $40^{\circ} \mathrm{C} / 75 \% \mathrm{RH}$ for $144 \mathrm{~h}$ and $288 \mathrm{~h}$. After specified time, the $25 \mathrm{~mL}$ flasks were completed up to the mark with mobile phase. For dry heat thermolysis, $62.5 \mathrm{mg}$ moxifloxacin and $125 \mathrm{mg}$ of prednisolone were mixed for 30 minutes in glass petty dish with spatula and placed in oven at $105^{\circ} \mathrm{C}$ for seven hours. After specified time, 5-7 mL methanol was added to the powder mixture and up to mark $50 \mathrm{~mL}$ with mobile phase. $1 \mathrm{~mL}$ of this solution was further diluted to $25 \mathrm{~mL}$ with mobile phase.

\section{Photolytic degradation studies}

For photolytic degradation study $1 \mathrm{~mL}$ of the standard stock solution was taken in $25 \mathrm{~mL}$ volumetric flask placed in the direct sunlight for $1 \mathrm{~h}$. After completion of the stress the $25 \mathrm{~mL}$ flask was completed up to the mark with mobile phase. 
Table 1 pH Optimization of phosphate buffer

\begin{tabular}{|c|c|c|c|c|c|}
\hline Mobile phase & $\begin{array}{l}\text { Retention } \\
\text { Capacity }\left(\mathbf{k}^{\prime}\right)\end{array}$ & $\begin{array}{l}\text { Theoretical } \\
\text { plates }(\mathrm{N})\end{array}$ & $\begin{array}{l}\text { Tailing } \\
\text { Factor }(\mathrm{T})\end{array}$ & $\begin{array}{l}\text { Resolution } \\
\text { (R) }\end{array}$ & $\begin{array}{l}\text { Peak } \\
\text { shape }\end{array}$ \\
\hline \multicolumn{6}{|c|}{ Methanol: Phosphate Buffer } \\
\hline \multicolumn{6}{|l|}{ pH 2.8 (62:38) } \\
\hline Moxifloxacin & & 4521 & 1.17 & & +++ \\
\hline Prednisolone & 0.92 & 6568 & 1.01 & 13.66 & +++ \\
\hline \multicolumn{6}{|c|}{ Methanol: Phosphate Buffer } \\
\hline \multicolumn{6}{|l|}{ pH 3.5 (62:38) } \\
\hline Moxifloxacin & & 4251 & 1.29 & & +++ \\
\hline Prednisolone & 0.84 & 5784 & 1.18 & 12.24 & +++ \\
\hline \multicolumn{6}{|c|}{ Methanol: Phosphate Buffer } \\
\hline \multicolumn{6}{|l|}{ pH 4.5 (62:38) } \\
\hline Moxifloxacin & & 4122 & 1.47 & & +++ \\
\hline Prednisolone & 0.54 & 5541 & 1.14 & 9.45 & - \\
\hline \multicolumn{6}{|c|}{ Methanol: Phosphate Buffer } \\
\hline \multicolumn{6}{|l|}{ pH 6.5 (62:38) } \\
\hline Moxifloxacin & & 3801 & 1.40 & & +++ \\
\hline Prednisolone & 0.41 & 4787 & 1.28 & 11.87 & - \\
\hline
\end{tabular}

Chromatographic conditions, mobile phase methanol: 0.018 M phosphate buffer 62:38, pH 2.8, or 3.5, or 4.5, or 6.5, Column BDS Hypersil C8 (250 X 4.6, $5 \mu$ m), flow rate $1.5 \mathrm{~mL} \mathrm{~min}^{-1}$,

injection volume $20 \mu \mathrm{L}$, wavelength $254 \mathrm{~nm},+++$ is peak acceptable and - is peak not acceptable.

\section{Robustness}

Premeditate variations were performed in the experimental conditions of the proposed method to assess the method robustness. For this intention, minor changes were made in mobile phase composition, flow rate and $\mathrm{pH}$ of buffer solution. The effect of these changes on chromatographic parameters such as retention time, tailing factor and number of theoretical plates was then measured.

\section{Limit of detection and limit of quantitation}

Limit of quantitation and limit of detection values were determined by the signal-to-noise $(\mathrm{S} / \mathrm{N})$ approach. Limit

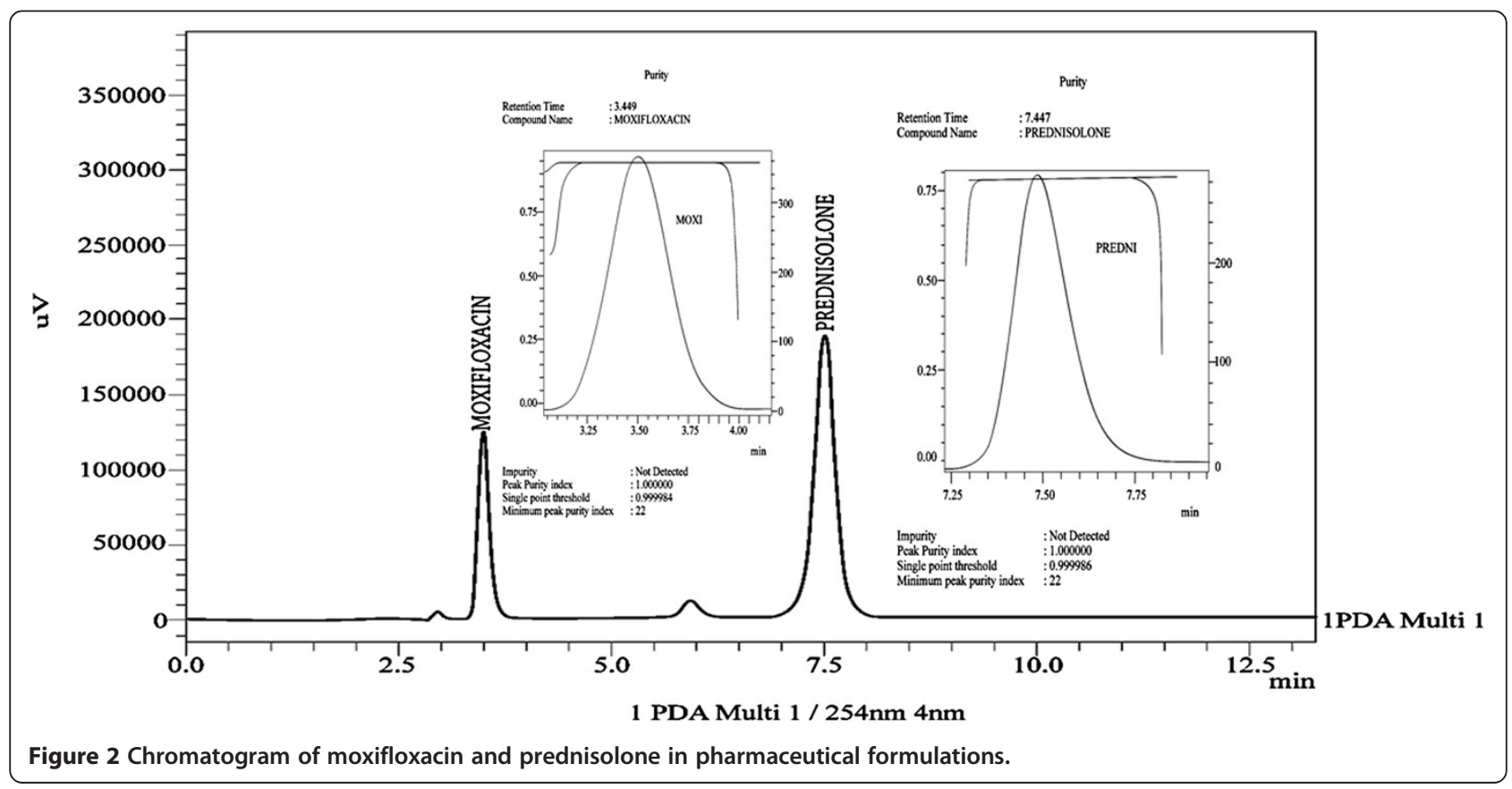


of quantitation is the concentration of the analyte that give a signal-to-noise $(\mathrm{S} / \mathrm{N})$ ratio of $10: 1$ at which analyte can be readily quantified with accuracy and precision. Limit of detection is the concentration of the analyte that give signal-to-noise $(\mathrm{S} / \mathrm{N})$ ratio of $3: 1$ at which analyte can be readily detected. To investigate the limit of quantitation and limit of detection solutions of different concentrations were prepared by spiking know amounts of moxifloxacin and prednisolone into excipients (benzalkonium chloride and sodium chloride). Each solution was prepared according to the procedure and analysed repeatedly to determine the $\mathrm{S} / \mathrm{N}$ ratio. The average $\mathrm{S} / \mathrm{N}$ ratio from all the analyses at each concentration level was used to calculate the limit of quantitation and limit of detection. The concentration level that gives an $\mathrm{S} / \mathrm{N}$ ratio of about 10:1 at which analytes can be readily quantified with accuracy and precision was reported as the limit of quantitation. The concentration level that gives an $\mathrm{S} / \mathrm{N}$ ratio of about $3: 1$ at which analytes can be readily detected was reported as the limit of detection.

\section{Results and discussion}

In reverse phase liquid chromatographic separation of pharmaceutical drugs, choice of a stationary phase depends on the chemical structures of the target analytes. Moxifloxacin and prednisolone drugs have high carbon to heteroatom ratio and therefore can be separated through $\mathrm{C} 8$ or $\mathrm{C} 18$ stationary phase based mainly on their overall hydrophobicity. Due to the presence of $\pi$ electrons, moxifloxacin and prednisolone also considered to be separated using phenyl stationary phase involving $\pi-\pi$ interactions between the phenyl groups in the stationary phase and any unsaturated bonds in moxifloxacin and prednisolone structures. Both the drugs also contains polar functional groups $(-\mathrm{COOH}$ or - $\mathrm{OH}$ etc.) and may be separated using cyano stationary phase involving dipole-dipole interactions.

Table 2 Accuracy of the proposed HPLC method

\begin{tabular}{|c|c|c|c|}
\hline \multirow[t]{2}{*}{ Drugs } & \multirow{2}{*}{$\begin{array}{l}\text { Spiked } \\
\text { concentration } \\
\left(\mu \mathrm{g} \mathrm{mL}^{-1}\right)\end{array}$} & \multirow{2}{*}{$\begin{array}{l}\text { Standard addition } \\
\text { Measured } \\
\text { concentration } \\
\left(\mu \mathrm{g} \mathrm{mL} \mathrm{m}^{-1}\right) \pm \mathrm{SD} ; \\
\mathrm{RSD}(\%)\end{array}$} & \multirow{2}{*}{$\begin{array}{l}\text { Synthetic mixtures } \\
\text { Measured } \\
\text { concentration } \\
\left(\mu \mathrm{g} \mathrm{mL} \mathrm{m}^{-1}\right) \pm \mathrm{SD} ; \\
\mathrm{RSD}(\%)\end{array}$} \\
\hline & & & \\
\hline \multirow[t]{3}{*}{ Moxifloxacin } & 25.0 & $25.2 \pm 0.1 ; 0.1$ & $24.8 \pm 0.2 ; 0.3$ \\
\hline & 50.0 & $50.4 \pm 0.9 ; 1.4$ & $50.6 \pm 0.4 ; 0.6$ \\
\hline & 75.0 & $76.8 \pm 1.1 ; 1.7$ & $74.8 \pm 1.1 ; 1.2$ \\
\hline \multirow[t]{3}{*}{ Prednisolone } & 50.0 & $50.9 \pm 0.7 ; 0.7$ & $50.1 \pm 0.9 ; 0.1$ \\
\hline & 100.0 & $98.4 \pm 0.9 ; 0.7$ & $99.7 \pm 0.8 ; 1.3$ \\
\hline & 150.0 & $147.9 \pm 0.7 ; 0.2$ & $150.0 \pm 0.5 ; 0.7$ \\
\hline
\end{tabular}

$n=$ Average of 5 analysis, Chromatographic conditions: mobile phase methanol: $18 \mathrm{mM}$ phosphate buffer 62:38, v/v, pH 2.8, Column BDS Hypersil C8 $(250 \times 4.6,5 \mu \mathrm{m})$, flow rate $1.5 \mathrm{~mL} \mathrm{~min}^{-1}$, injection volume $20 \mu \mathrm{L}$, wavelength $254 \mathrm{~nm}$.
Table 3 Intra-Day and Inter-Day precision of the proposed HPLC method

\begin{tabular}{|c|c|c|c|}
\hline \multirow[t]{2}{*}{ Drugs } & \multirow{2}{*}{$\begin{array}{l}\text { Actual } \\
\text { concentration } \\
\left(\mu \mathrm{g} \mathrm{mL}^{-1}\right)\end{array}$} & Intra-day precision & Inter-day precision \\
\hline & & $\begin{array}{l}\text { Measured } \\
\text { concentrations; } \\
\text { RSD (\%) }\end{array}$ & $\begin{array}{l}\text { Measured } \\
\text { concentrations; } \\
\text { RSD (\%) }\end{array}$ \\
\hline \multirow[t]{3}{*}{ Moxifloxacin } & 25.0 & $24.8 \pm 0.6 ; 1.7$ & $25.3 \pm 0.4 ; 1.1$ \\
\hline & 50.0 & $50.5 \pm 0.7 ; 0.2$ & $51.2 \pm 0.8 ; 1.0$ \\
\hline & 75.0 & $74.1 \pm 0.4 ; 1.5$ & $75.7 \pm 1.2 ; 1.5$ \\
\hline \multirow[t]{3}{*}{ Prednisolone } & 50.0 & $50.0 \pm 0.1 ; 0.3$ & $50.4 \pm 1.7 ; 1.0$ \\
\hline & 100.0 & $101.5 \pm 0.4 ; 0.9$ & $102.0 \pm 0.9 ; 0.5$ \\
\hline & 150.0 & $153.1 \pm 0.8 ; 1.7$ & $151.8 \pm 0.7 ; 1.6$ \\
\hline
\end{tabular}

$n=$ Average of 5 analysis, Chromatographic conditions: mobile phase methanol: $18 \mathrm{mM}$ phosphate buffer 62:38, v/v, pH 2.8, Column BDS Hypersil $\mathrm{C} 8(250 \times 4.6,5 \mu \mathrm{m})$, flow rate $1.5 \mathrm{~mL} \mathrm{~min}^{-1}$, injection volume $20 \mu \mathrm{L}$, wavelength $254 \mathrm{~nm}$.

In this work we proposed a simple, fast, and accurate stability indicating RP-HPLC method for simultaneous determination of moxifloxacin and prednisolone. For optimization of the chromatographic conditions and to obtain symmetrical peaks with better resolution and with no peak impurity, various chromatographic conditions such as composition of mobile phase, mobile phases with different $\mathrm{pH}$, stationary phases with different packing materials (Hypersil BDS C8, Hypersil ODS C18, Hypersil BDS Phenyl-2, and Hypersil BDS Cyano) and configurations $(10,15,25 \mathrm{~cm}$ columns) were applied to moxifloxacin and prednisolone combination.

Optimization of mobile phase, stationary phase and $\mathrm{pH}$ Method development process was initiated with different ratios (20:80, 30:70, 40:60 and 50:50) of water and methanol at different $\mathrm{pH}$. With methanol and water broad peaks of prednisolone and asymmetrical peaks of moxifloxacin were obtained on all four different stationary phases (Hypersil BDS C8, Hypersil ODS C18, Hypersil BDS Phenyl-2, and Hypersil BDS Cyano) with long retention of prednisolone on C18 column. Increase

Table 4 Robustness study of moxifloxacin

\begin{tabular}{lrccc}
\hline $\begin{array}{l}\text { Chromatographic } \\
\text { conditions }\end{array}$ & Assay $\%$ & $\mathbf{t}_{\mathbf{R}}(\mathbf{m i n})$ & $\begin{array}{l}\text { Theoretical } \\
\text { plates }\end{array}$ & Tailing \\
\hline Methanol:buffer (64:36) & 99.1 & 3.241 & 4347 & 1.26 \\
Methanol:buffer (62:38) & 102.0 & 3.446 & 4328 & 1.26 \\
Methanol:buffer (60:40) & 100.5 & 3.615 & 4498 & 1.24 \\
Flow rate (1.3 mL/min) & 100.8 & 3.825 & 4448 & 1.26 \\
Flow rate (1.5 mL/min) & 98.4 & 3.447 & 4319 & 1.26 \\
Flow rate (1.7 mL/min) & 98.2 & 3.089 & 4358 & 1.26 \\
Buffer (pH 2.6) & 101.0 & 3.442 & 4348 & 1.24 \\
Buffer (pH 2.8) & 100.9 & 3.446 & 4442 & 1.26 \\
Buffer (pH 3.0) & 101.2 & 3.443 & 4488 & 1.24 \\
\hline
\end{tabular}


Table 5 Robustness Study of Prednisolone

\begin{tabular}{lrrll}
\hline $\begin{array}{l}\text { Chromatographic } \\
\text { Conditions }\end{array}$ & Assay $\%$ & $\mathbf{t}_{\mathbf{R}}(\mathbf{m i n})$ & $\begin{array}{l}\text { Theoretical } \\
\text { plates }\end{array}$ & Tailing \\
\hline Methanol:buffer (64:36) & 99.2 & 6.947 & 6328 & 1.01 \\
Methanol:buffer (62:38) & 100.8 & 7.447 & 6277 & 1.01 \\
Methanol:buffer (60:40) & 99.7 & 8.499 & 6341 & 1.01 \\
Flow rate (1.3 mL/min) & 99.4 & 8.433 & 6358 & 1.01 \\
Flow rate (1.5 mL/min) & 100.5 & 7.447 & 6249 & 1.02 \\
Flow rate (1.7 mL/min) & 100.4 & 6.569 & 6371 & 1.01 \\
Buffer (pH 2.6) & 100.4 & 7.497 & 6395 & 1.00 \\
Buffer (pH 2.8) & 99.9 & 7.447 & 6354 & 1.02 \\
Buffer (pH 3.0) & 98.8 & 7.498 & 6248 & 1.00 \\
\hline
\end{tabular}

in the temperature of column oven to $50^{\circ} \mathrm{C}$ did not improve peak tailing and broadening of analytes. The peak tailing of moxifloxacin may be due to the chelate formation of metal ion impurity of the stationary phases with the carboxyl group of $\mathrm{C}-3$ and oxygen atom of C-4 of moxifloxacin or it may be caused due to unwanted interactions between nitrogen atoms (of moxifloxacin) and silanol residues of stationary phases. The peak broadening of prednisolone may be due to low polarity of the mobile phase. Then polarity of the mobile phase was increased by using phosphate buffer in the mobile phase composition. Further chromatographic experiments were performed on four different stationary phases (Hypersil BDS C8, Hypersil ODS C18, Hypersil BDS Phenyl-2, and Hypersil BDS Cyano) using methanol: phosphate buffer as mobile phase along with $(0.1 \% \mathrm{v} / \mathrm{v})$ triethylamine (as silanol blocker). Highly symmetrical and sharp peaks of moxifloxacin and prednisolone were obtained with methanol: $0.018 \mathrm{M}$ phosphate buffer containing $0.1 \% \mathrm{v} / \mathrm{v}$ triethylamine $(62: 38, \mathrm{v} / \mathrm{v})$ on Hypersil BDS C8 columns (with better resolution, capacity factor, peak shapes and theoretical plates) as compared to other stationary phases (Hypersil ODS C18, Hypersil BDS Phenyl2, and Hypersil BDS Cyano). The variations in the composition of the mobile phase and dissimilar stationary phases had substantial influences on peak shape, tailing factor, retention factor, theoretical plates and resolution.

In order to optimize the appropriate $\mathrm{pH}$ of the phosphate buffer solution, chromatographic experiments were performed at four different $\mathrm{pH}(2.8,3.5,4.5$ and 6.5) values of the buffer solution. Mobile phase was prepared in the ratio of methanol: phosphate buffer (62: 38, $\mathrm{v} / \mathrm{v})$ containing $0.1 \% \mathrm{v} / \mathrm{v}$ triethylamine. Hypersil BDS C8 column was used as stationary phase to optimize the appropriate $\mathrm{pH}$. Highly symmetrical and sharp peaks of moxifloxacin and prednisolone were obtained at $\mathrm{pH} 2.8$ and 3.5 by using methanol: $0.018 \mathrm{M}$ phosphate buffer with better resolution, capacity factor, and theoretical plates at $\mathrm{pH} 2.8$ as compared to $\mathrm{pH} 3.5$ [Table 1]. Finally, methanol: phosphate buffer $0.018 \mathrm{M}, \mathrm{pH} 2.8(62: 38, \mathrm{v} / \mathrm{v})$ was selected which provided symmetrical peaks with acceptable peak purity index of moxifloxacin and prednisolone using Hypersil BDS C8 column. Under the mentioned chromatographic conditions highly symmetrical and sharp peaks of moxifloxacin and prednisolone were obtained at retention times of 3.449, and 7.447 min, respectively [Figure 2].

The developed chromatographic method was validated using ICH guidelines [24]. Validation parameters

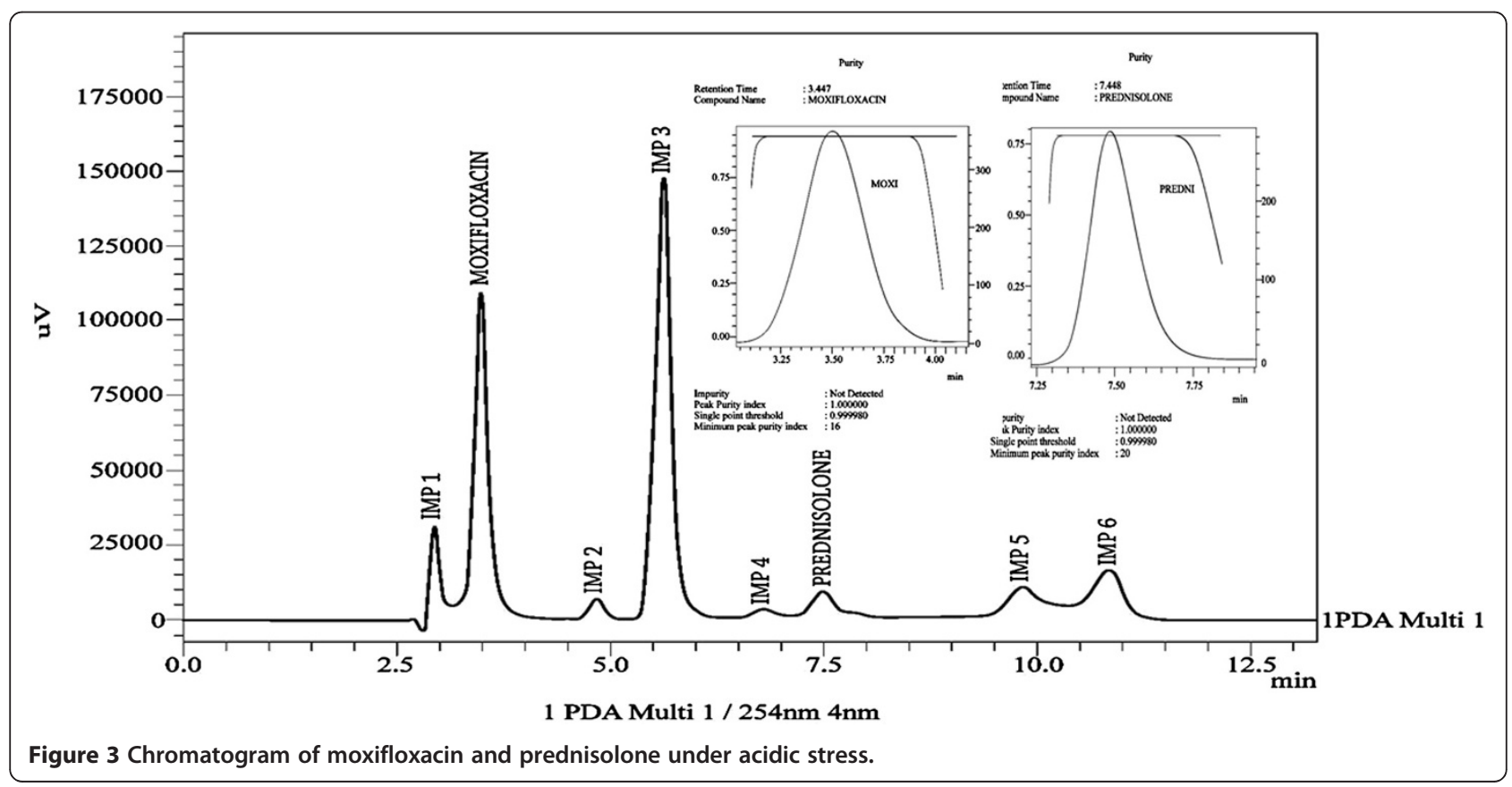




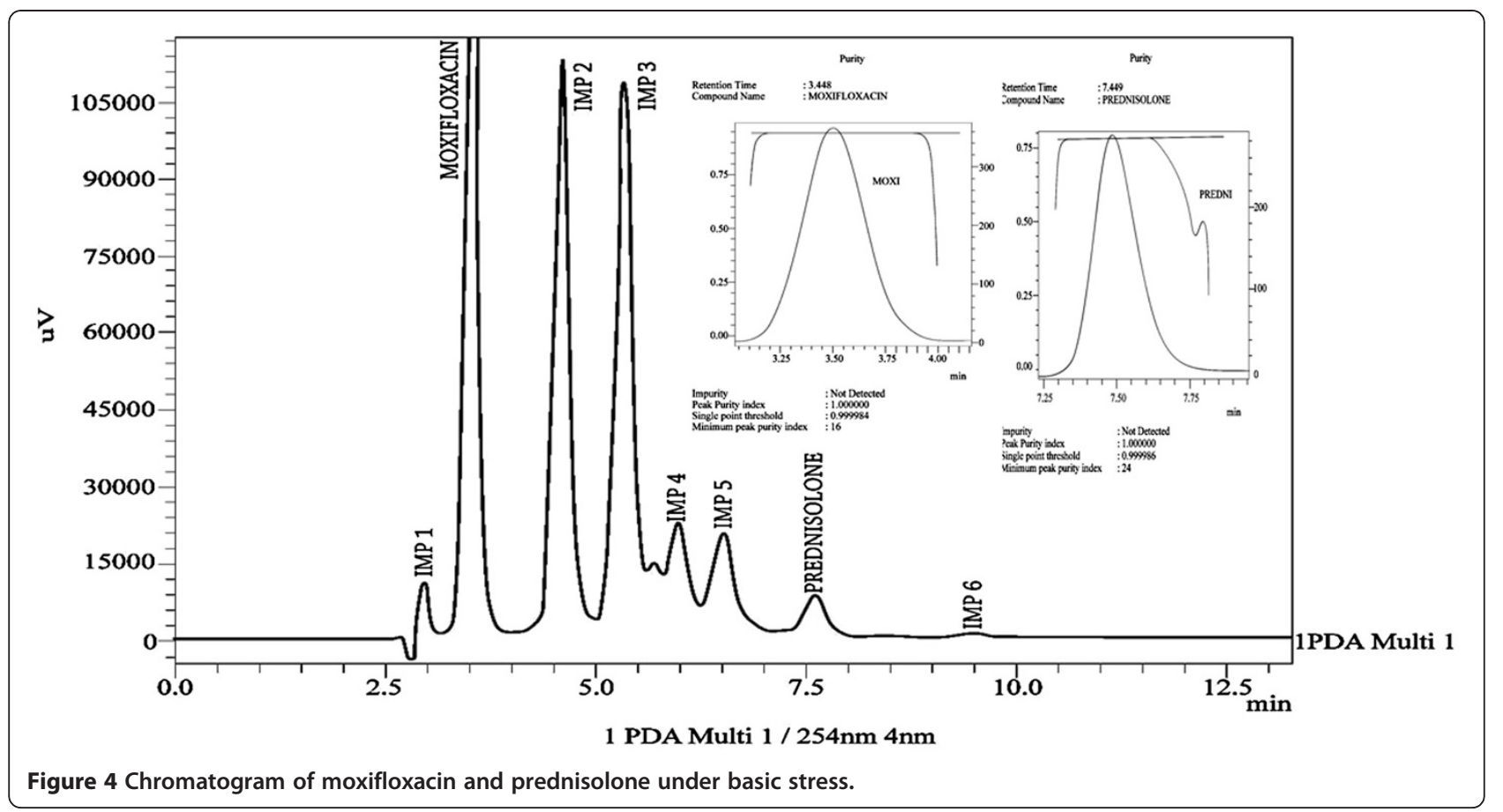

included linearity, accuracy, precision, robustness, specificity, limit of detection and quantitation.

Linear calibration plots for the proposed method were obtained in concentration ranges of $20-80 \mu \mathrm{g} \mathrm{mL}^{-1}(20$, $30,40,50,60,70$ and $\left.80 \mu \mathrm{g} \mathrm{mL}^{-1}\right)$ for moxifloxacin and $40-160 \mu \mathrm{g} \mathrm{mL}^{-1}$ prednisolone $(40,60,80,100,120,140$ and $\left.160 \mu \mathrm{g} \mathrm{mL} \mathrm{m}^{-1}\right)$. The linear regression equation $\left(r^{2} \geq 0.998\right)$ for moxifloxacin was found to be $Y=22711$ $\mathrm{X}+23429(\mathrm{Y}=\mathrm{aX}+\mathrm{b})$ in which $\mathrm{Y}$ is the dependent variable, $\mathrm{X}$ is independent variable, 22711 is slope (denoted by a) which shows change in dependent $(Y)$ variable per unit change in independent $(\mathrm{X})$ variable and 23429 (denoted by b) is the Y-intercept i.e., the value of $\mathrm{Y}$ variable when $\mathrm{X}=0$. The linear regression equation $\left(\mathrm{r}^{2} \geq 0.999\right)$ for prednisolone was $\mathrm{Y}=69932 \mathrm{X}+73339$ $(\mathrm{Y}=\mathrm{aX}+\mathrm{b})$ in which 69932 is the slope (a) and 73339 is the Y-intercept (a point of the Y-coordinate where a given line intersects the $\mathrm{Y}$-axis) at which $\mathrm{X}$ is equal to

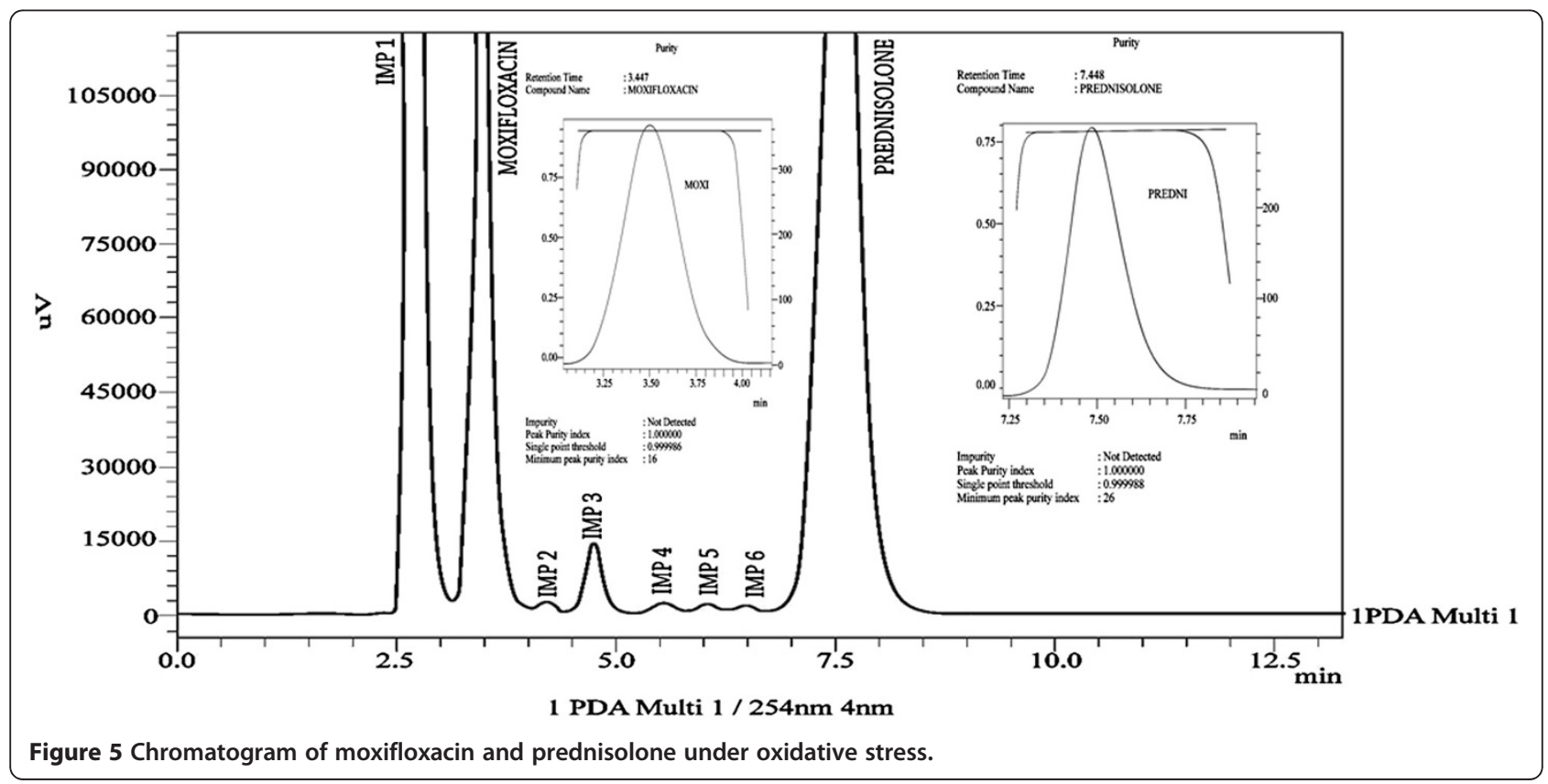




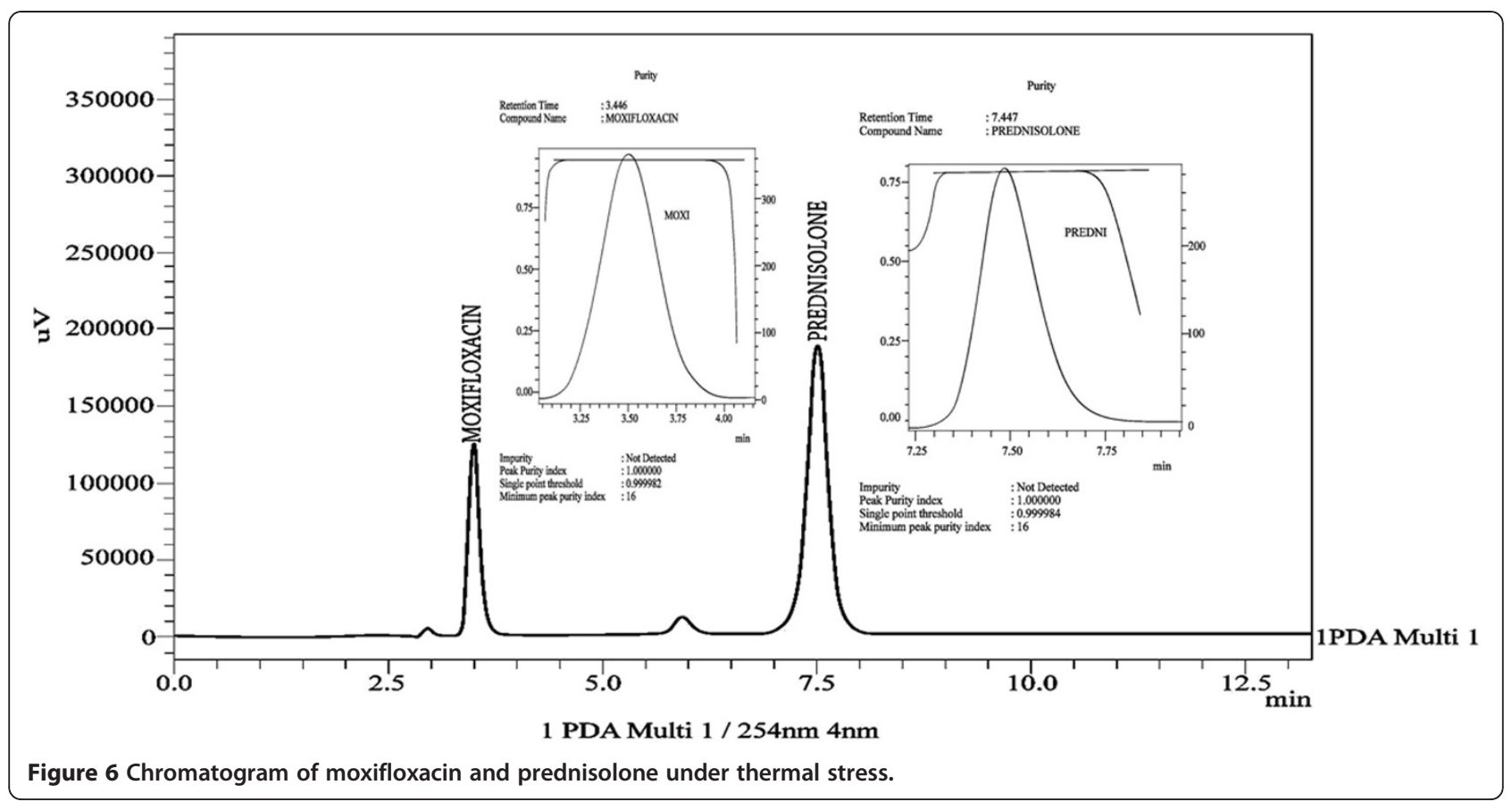

zero. It defines the elevation of the line. The Y-intercept provides with an estimate of the variability of the method. For example, the ratio percent of the Yintercept with the variable data at nominal concentration is used to estimate the method variability.

The limit of detection (LOD) and quantitation (LOQ) were determined by making serials of dilutions. LOD was found to be $0.088 \mu \mathrm{g} \mathrm{mL} L^{-1}$ and $0.175 \mu \mathrm{g} \mathrm{mL} L^{-1}$ for moxifloxacin and prednisolone, respectively (signal to noise ratio of $3: 1$ ). LOQ was found to be $0.284 \mu \mathrm{g} \mathrm{mL}{ }^{-1}$ and $0.559 \mu \mathrm{g} \mathrm{mL} \mathrm{m}^{-1}$ for moxifloxacin and prednisolone, respectively (signal to noise ratio of 10:1).

Accuracy of the developed method was performed by the standard addition and synthetic mixture techniques. Three levels of solutions (50, 100 and 150\%) of the nominal analytical concentrations were prepared and

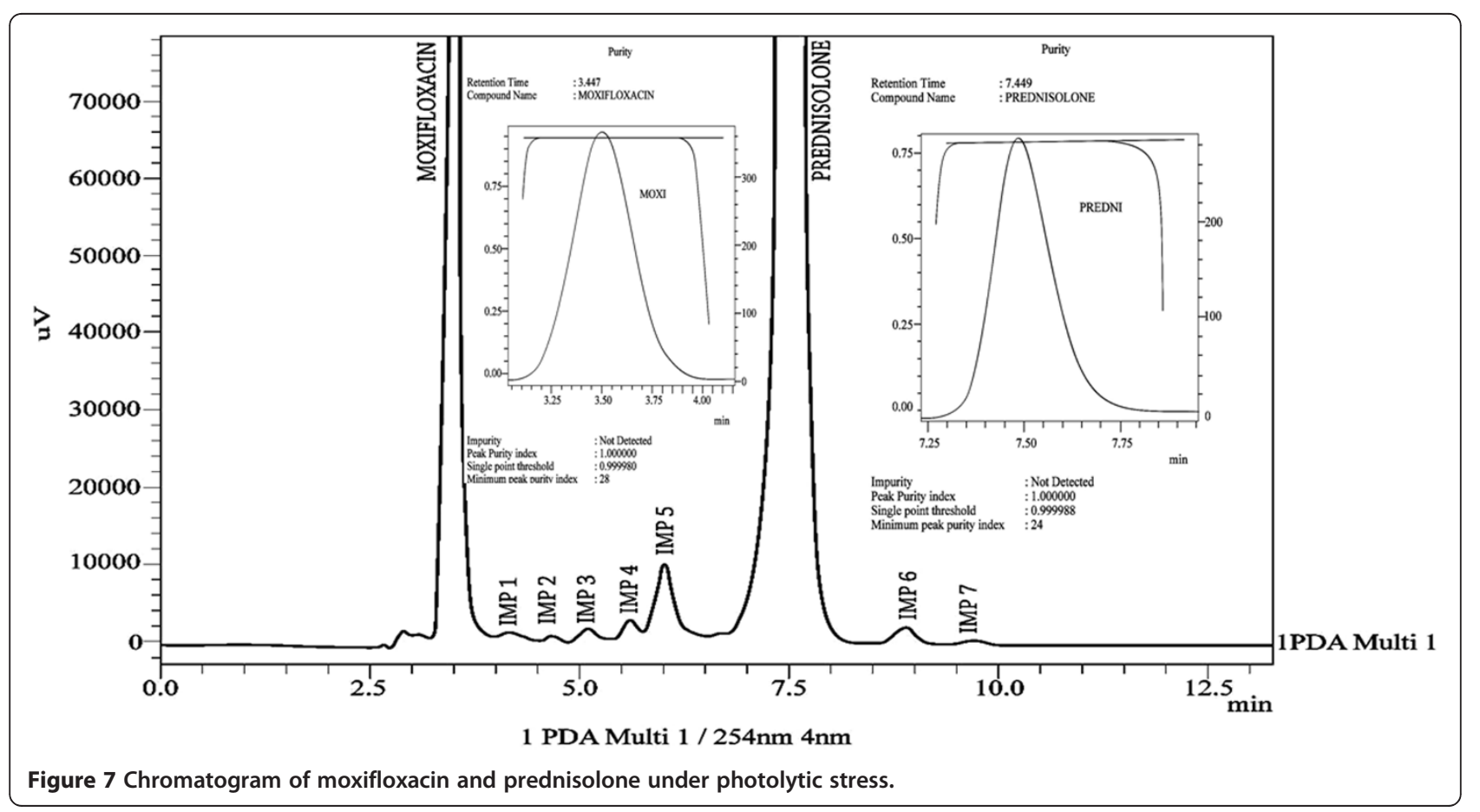


Table 6 Stress Testing Results of Moxifloxacin and Prednisolone

\begin{tabular}{|c|c|c|c|c|c|}
\hline \multirow[t]{2}{*}{ Nature of stress } & \multirow[t]{2}{*}{ Storage conditions } & \multirow[t]{2}{*}{ Time (h) } & \multirow{2}{*}{$\frac{\text { Amount of moxifloxacin }}{\text { Remaining } \pm \text { RSD (\%) }}$} & \multirow{2}{*}{$\frac{\text { Amount of prednisolone }}{\text { Remaining } \pm \text { RSD (\%) }}$} & \multirow{2}{*}{$\begin{array}{l}\text { Extent of } \\
\text { decomposition }\end{array}$} \\
\hline & & & & & \\
\hline $5 \mathrm{M} \mathrm{HCl}$ & $\left(40^{\circ} \mathrm{C} / 75 \% \mathrm{RH}\right)$ & 16 & $86.3 \pm 3.4(\mathrm{PPI}=1.0000)$ & $4.8 \pm 3.0(\mathrm{PPI}=1.0000)$ & Substantial \\
\hline $5 \mathrm{M} \mathrm{NaOH}$ & $\left(22^{\circ} \mathrm{C} / 58 \% \mathrm{RH}\right)$ & 0.67 & $100.0 \pm 2.1(\mathrm{PPI}=1.0000)$ & $3.4 \pm 2.7(\mathrm{PPI}=1.0000)$ & Substantial \\
\hline $6 \% \mathrm{H}_{2} \mathrm{O}_{2}$ & $\left(40^{\circ} \mathrm{C} / 75 \% \mathrm{RH}\right)$ & 16 & $96.4 \pm 1.5(\mathrm{PPI}=1.0000)$ & $88.3 \pm 1.4(\mathrm{PPI}=\mathbf{1 . 0 0 0 0})$ & Substantial \\
\hline \multirow[t]{2}{*}{ Thermal } & $\left(40^{\circ} \mathrm{C} / 75 \% \mathrm{RH}\right)$ & 144 & $101.3 \pm 1.4(\mathrm{PPI}=\mathbf{1 . 0 0 0 0})$ & $100.5 \pm 1.9(\mathrm{PPI}=\mathbf{1 . 0 0 0 0})$ & None \\
\hline & $\left(40^{\circ} \mathrm{C} / 75 \% \mathrm{RH}\right)$ & 288 & $97.5 \pm 1.1(\mathrm{PPI}=\mathbf{1 . 0 0 0 0})$ & $97.2 \pm 1.5(\mathrm{PPI}=1.0000)$ & None \\
\hline Dry Heat & $\left(105^{\circ} \mathrm{C}\right)$ & 7 & $93.7 \pm 1.7(\mathrm{PPI}=\mathbf{1 . 0 0 0 0})$ & $84.1 \pm 1.4(\mathrm{PPI}=\mathbf{1 . 0 0 0 0})$ & Substantial \\
\hline Photolytic & Sunlight & 1 & $88.5 \pm 1.9(\mathrm{PPI}=\mathbf{1 . 0 0 0 0})$ & $94.5 \pm 2.5(\mathrm{PPI}=\mathbf{1 . 0 0 0 0})$ & Substantial \\
\hline
\end{tabular}

$n=$ Average of 3 determinations, $P P I=$ Peak Purity Index, Chromatographic conditions: mobile phase Methanol: $18 \mathrm{mM}$ phosphate buffer 62:38, v/v, pH 2.8, Column BDS Hypersil C8 (250 X 4.6, $5 \mu \mathrm{m})$, flow rate $1.5 \mathrm{~mL} \mathrm{~min}{ }^{-1}$, injection volume $20 \mu \mathrm{L}$, wavelength $254 \mathrm{~nm}$.

analysed by the developed method. Percentage recoveries along with standard deviation and relative standard deviations for each analyte are given in [Table 2]. Recovery studies showed the method to be highly accurate and suitable for intended use.

Intra-day precision was determined by injecting five standard solutions of three different concentrations on the same day and inter-day precision was determined by injecting the same solutions for three consecutive days. Relative standard deviation (RSD \%) of the peak area calculated to represent precision. The results of intraday and inter-day precision are presented in [Table 3].

Robustness of the method was performed by slightly varying the chromatographic conditions. The results showed that slight variations in chromatographic conditions had negligible effect on the chromatographic parameters [Table 4 and Table 5].

Specificity of the developed method was evaluated by applying different stress conditions (acid, base, oxidation, thermal and photolytic) to moxifloxacin and prednisolone in combination form. The chromatograms under different stress conditions are showed in [Figures 3, 4, 5, $6,7]$. The results of stress studies are given in [Table 6].

All the stress conditions applied were enough to degrade both the drugs. Comparison of the two drugs showed that moxifloxacin is more stable as compared to prednisolone. Under acidic conditions prednisolone was degraded up to $95.2 \%$ and moxifloxacin was degraded up to $13.7 \%$. Under basic stress prednisolone was degraded up to $96.6 \%$ and moxifloxacin was found to be stable under basic stress. Under oxidative stress prednisolone was degraded up to $11.7 \%$ and moxifloxacin was found to be stable under oxidative stress. Under thermal stress (dry heat) moxifloxacin was degraded up to $6.3 \%$ and prednisolone was degraded up to $15.9 \%$. Under photolytic stress prednisolone and moxifloxacin were degraded up to $5.5 \%$ and $11.5 \%$, respectively. From these stress studies it is thus concluded that prednisolone and moxifloxacin drugs are not stable in basic, acidic, oxidative, thermal and photolytic stress conditions.
In addition to the percentage degradation of each drug, a number of degradation products (impurities) were produced under acidic (6 impurity/degradation peaks with IMP 3 as major degradation peak), basic (6 impurity/degradation peaks with IMP 2 and IMP 3 as major degradation peaks), oxidative (6 impurity/ degradation peaks with IMP 1 as degradation peak) and photolytic stress (7 impurity/degradation peaks with IMP 5 as major degradation peak) conditions. The developed method effectively separated the degradation products or impurities (6 impurity peaks under acidic stress, 6 impurity peaks under basic stress, 6 impurity peaks under oxidative stress, 7 impurity peaks under photolytic stress,) from analyte peaks [Figures 3, 4, 5, 6, 7]. Therefore, the developed method is to be considered highly specific for intended use. Application of the developed method was checked by analyzing the moxifloxacin and prednisolone in commercially available pharmaceutical products. The results are provided in [Table 7] which showed high percentage recoveries and low RSD (\%) values for both analytes.

\section{Conclusion}

A simple, fast and accurate stability indicating RP-HPLC method is described for simultaneous determination of moxifloxacin and prednisolone in pharmaceutical formulations. The developed method was validated by

Table 7 Assay results of moxifloxacin and prednisolone in commercial eye drops

\begin{tabular}{|c|c|c|c|}
\hline Products & Ingredient & $\begin{array}{l}\text { Label value } \\
\text { (mg per } \mathrm{mL} \text { ) }\end{array}$ & $\begin{array}{l}\% \text { Recovery } \\
\pm \text { RSD (\%) }\end{array}$ \\
\hline \multicolumn{4}{|l|}{ Eye drops } \\
\hline \multirow[t]{2}{*}{ Occumox P } & Moxifloxacin & 5 & $100.3 \pm 0.3$ \\
\hline & Prednisolone & 10 & $99.0 \pm 0.7$ \\
\hline \multirow[t]{2}{*}{ Moftrex P } & Moxifloxacin & 5 & $100.7 \pm 0.1$ \\
\hline & Prednisolone & 10 & $98.9 \pm 0.7$ \\
\hline
\end{tabular}

$n=$ Average of 10 determinations, Chromatographic conditions: mobile phase Methanol: $18 \mathrm{mM}$ phosphate buffer 62:38, v/v, pH 2.8, Column BDS Hypersil $\mathrm{C} 8(250 \times 4.6,5 \mu \mathrm{m})$, flow rate $1.5 \mathrm{~mL} \mathrm{~min}^{-1}$, injection volume $20 \mu \mathrm{L}$, wavelength $254 \mathrm{~nm}$. 
testing its linearity, accuracy, precision, limits of detection and quantitation and specificity. The method is simple, fast and is without the use of ion pair or any derivatization reagent. The method is good enough to separate the peaks of active pharmaceutical ingredients (APIs) from the degradation products (produced during forced degradation studies). So, it is concluded that the method can be successfully used for any kind of stability and validation studies.

\section{Competing interests}

The authors declare that they have no competing interests.

\section{Authors' contributions}

SNR: Participated in method development and optimization, collect the literature review, performed forced degradation studies and wrote the manuscript. IUK: proposed, planned and supervised the whole work. SSR and IM: Participated in the method validation. All authors read and approved the final manuscript.

\section{Author details}

'Department of Chemistry, Government College University, Lahore 54000, Pakistan. ${ }^{2}$ Department of Chemistry, Queen Marry College, Lahore 54000, Pakistan. ${ }^{3}$ Medipharm Pharmaceuticals Kot Lakhpat, Lahore 54000, Pakistan.

Received: 24 June 2012 Accepted: 28 August 2012

Published: 4 September 2012

\section{References}

1. Sweetman SC: Martindale: The complete drug reference. 36th edition. Lon: The pharm. press; 2009:302

2. Sweetman SC: Martindale: The complete drug reference. 36th edition. Lon: The pharm. press; 2009:1540.

3. Misra M, Misra AK, Zope P, Panpalia GM, Dorle AK: Simple and validated UV-Spectroscopic method for estimation of moxifloxacin in bulk and formulation. JGPT 2010, 2:21-27.

4. Chaudhary AK: A novel and validated UV-Spectorphotometric method for estimation of moxifloxacin in tablets. AJPSP 2010, 1:50-56.

5. Sanjay K, Motwani CS, Ahmad FJ, Khar RK: Validated spectrophotometric methods for the estimation of moxifloxacin in bulk and pharmaceutical formulations. Spectrochim Acta 2007, 68:250-256.

6. Sultana N, Akhtar M, Shamim S, Gul S: Simultaneous determination of moxifloxacin and $\mathrm{H} 2$ receptor antagonist in pharmaceutical dosage formulations by RP-HPLC: application to in vitro drug interactions. Quim Nova 2011, 34:683-688.

7. Sultana N, Arayne MS, Akhtar M, Shamim S, Gula S, Khan MM: High performance liquid chromatography assay for moxifloxacin in bulk, pharmaceutical formulations and serum: application to in-vitro metal interactions. J Chin Chem Soc 2010, 57:708-711.

8. Lemus JM, Arroyo GJ: Determination of prednisolone acetate, sulfacetamide and phenylefrine in local pharmaceutical preparations using micellar electrokinetic chromatography. J Pharm Biomed Anal 2003, 31:873-884

9. Barot HN, Dave JB, Patel CN: Development and validation of spectrophotometric method for simultaneous determination of prednisolone acetate and ofloxacin in eye drop. IJPSR 2012, 3:1817-1821.

10. Prasad VK, Haneke HB: Simultaneous determination of prednisolone acetate, prednisolone, prednisone, cortisone and hydrocortisone in swine plasma using solid-phase and liquid-liquid extraction techniques. J Chromatogr 1986, 378:305-316.

11. Singh DK, Verma R: Comparison of second derivative-spectrophotometric and reversed-phase HPLC methods for the determination of prednisolone in pharmaceutical formulations. Anal Sci 2007, 23:1241-1243.

12. Musharraf SJ, Fatima U, Sultana R: Stress degradation studies and development of stability-indicating TLC-densitometry method for determination of prednisolone acetate and chloramphenicol in their individual and combined pharmaceutical formulations. Chem Cent J 2012, 6:7.
13. Qutab SS, Razzaq SN, Ashfaq M, Shuja ZA, Khan IU: Simple and sensitive LC-UV method for simultaneous analysis of hydrochlorothiazide and candesartan cilexetil in pharmaceutical formulations. Acta Chromatogra 2007, 19:119-129.

14. Ashfaq M, Khan IU, Qutab SS, Razzaq SN: HPLC determination of ezetimibe and simvastatin in pharmaceutical formulations. J Chil Chem Soc 2007, 52:1220-1223

15. Qutab SS, Razzaq SN, Khan IU, Ashfaq M, Shuja ZA: Simultaneous determination of atorvastatin calcium and ezetimibe in pharmaceutical formulations by liquid chromatography. J Food Drug Anal 2007, 15:139-144.

16. Ashfaq M, Khan IU, Asghar MN: Development and validation of liquid chromatographic method for gemfibrozil and simvastatin in binary combination. J Chil Chem Soc 2008, 53:1617-1619.

17. Khan IU, Sharif S, Ashfaq M, Asghar MN: Simultaneous determination of potassium clavulanate and cefixime in synthetic mixtures by high performance liquid chromatography. J AOAC Int 2008, 91:744-749.

18. Qutab SS, Razzaq SN, Ashfaq M, Khan IU, Mumtaz AM: Simultaneous quantitation of olmesartan medoximil and amlodipine besylate in combined tablets using HPLC. J Chil Chem Soc 2008, 54:234-237.

19. Khan IU, Jillani SM, Ashfaq M: Determination of atorvastatin and gemfibrozil in human plasma by reversed-phase liquid chromatography. Lat Am J Pharm 2010, 29:1383-1388.

20. Khan IU, Kausar T, Ashfaq M, Sharif S: Development and validation of liquid chromatographic method for the simultaneous estimation of ezetimibe and lovastatin in human plasma. J Chil Chem Soc 2010, 55:461-464.

21. Sharif S, Khan IU, Ashfaq M, labal MS, Ahmad S: Development and validation of a high performance liquid chromatographic method for the simultaneous determination of potassium clavulanate and cefadroxil in synthetically prepared tablets. J Anal Chem 2010, 65:1029-1034.

22. Razzaq SN, Mariam I, Khan IU, Ashfaq M: Development and validation of liquid chromatographic method for gatifloxacin and ketorolac tromethamine in combined dosage form. I Liq Chromatogr Related Technol 2012, 35:651-661.

23. Razzaq SN, Ashfaq M, Khan IU, Mariam I: Development and validation of liquid chromatographic method for moxifloxacin and ketorolac tromethamine in combined dosage form. Quim Nova 2012, 35:1216-1221.

24. ICH (Q2B): Note for guidance on validation of analytical procedures: methodology. Geneva: International conference on Harmonization, IFPMA; 1996.

doi:10.1186/1752-153X-6-94

Cite this article as: Razzaq et al: Stability indicating HPLC method for the simultaneous determination of moxifloxacin and prednisolone in pharmaceutical formulations. Chemistry Central Journal 2012 6:94.

\section{Publish with ChemistryCentral and every scientist can read your work free of charge \\ "Open access provides opportunities to our colleagues in other parts of the globe, by allowing anyone to view the content free of charge." W. Jeffery Hurst, The Hershey Company.}

- available free of charge to the entire scientific community

- peer reviewed and published immediately upon acceptance

- cited in PubMed and archived on PubMed Central

- yours - you keep the copyright

Submit your manuscript here:

http://www.chemistrycentral.com/manuscript/<smiles>c1ccccc1</smiles>

ChemistryCentral 